\title{
HUMANISME DALAM PENDIDIKAN ISLAM: KONSEPSI PENDIDIKAN RAMAH ANAK
}

\author{
Abd. Azis \\ (STIT Al Ibrohimy Galis Bangkalan)
}

\begin{abstract}
Abstrak:
Tulisan ini mendeskripsikan humanisme dalam pendidikan Islam melalui model pembelajaran ramah anak. Melalui kajian literatur diperoleh hasil bahwa konsep pembelajaran ramah anak menjadi penting seiring masih maraknya kekerasan terhadap anak baik di dalam ataupun di luar institusi pendidikan. Dalam model pendidikan ini, pendidikan Islam menjadi katalis untuk mewujudkan humanisasi dalam pendidikan. Konsep ramah anak berupaya menciptakan pembelajaran yang menyenangkan dan membuat siswa merasa betah dan nyaman di sekolah. Hal tersebut dapat dilihat dari sikap guru yang ramah terhadap siswa, proses pembelajaran efektif, pengelolaan kelas efektif dan lingkungan belajar kondusif, serta motivasi belajar siswa. Dalam hal internalisasi nilai-nilai keislaman, guru menanamkan sikap sabar dan mampu menjadi teladan bagi siswa, menggunakan metode yang bervariatif, menerapkan pengelolaan kelas yang menyenangkan dan didukung lingkungan belajar yang kondusif.
\end{abstract}

Kata Kunci: Humanisme; Pendidikan Islam; Pendidikan Ramah Anak; Nilai-nilai Keislaman. 


\begin{abstract}
:
This paper describes humanism in Islamic education through child-friendly education model. Literary study results in the importance of such education model along with the increase of violence towards children either in educational institutions or in outside the area. In the child-friendly education, Islamic education is a catalyst to achieve humanism in education. The education model focuses on creating fun interaction and makes students feeling at home and safe at school. This can be seen from friendly teachers' attitudes, effective learning processes, effective classroom management, conducive learning environment, and students' motivation. In terms of Islamic values internalization, teacher cultivates patient attitudes and becomes model for students, implementing variety of learing methods, implementing positive classroom management within conducive learning environment.
\end{abstract}

\title{
Keywords: Humanism; Islamic Education; Child-Friendly Education;
} Islamic Values.

\section{A. Pendahuluan}

Belajar pada dasarnya dapat dipandang sebagai suatu proses perubahan positif-kualitatif yang terjadi pada tingkah laku siswa sebagai subyek didik akibat adanya peningkatan pengetahuan, keterampilan, nilai, sikap, minat, apresiasi, kemampuan berfikir logis dan kritis, kemampuan interaktif dan kreatifitas yang telah dicapainya. Konsep belajar demikian menempatkan manusia yang belajar tidak hanya pada proses teknis, tetapi sekaligus pada proses normatif. Hal ini amat penting agar perkembangan kepribadian dan kemampuan belajar siswa terjadi secara harmonis dan optimal. ${ }^{1}$

Proses belajar bisa berlangsung secara efektif apabila semua faktor internal (dari dalam diri siswa) dan faktor eksternal (dari luar diri siswa) diperhatikan oleh guru. Seorang guru harus bisa mengetahui potensi, kecerdasan, minat, motivasi, gaya belajar, sikap, dan latar belakang sosial ekonomi dan budaya yang merupakan faktor internal siswa. Begitu juga faktor eksternal seperti tujuan, materi, strategi, pendekatan pembelajaran, metode, iklim sosial dalam kelas, sistem evaluasi dan lain-lain.

Sistem pendidikan yang ada sekarang hanya menganggap siswa sebagai bejana kosong yang perlu diisi, bukan menyalakan semangat agar siswa bergairah belajar. Karena tujuannya untuk mengisi bejana, maka siswa sering dijejali dengan berbagai materi pelajaran sebanyak-banyaknya. Waktu belajar siswa di

1 Najib Sulhan, Pembangunan Karakter Pada Anak, Manajemen Pembelajaran Guru Menuju Sekolah Efektif (Surabaya: Intelaktual Club, 2006), 5. 
sekolah selama 6-7 jam sehari, serasa belum cukup sehingga para murid perlu diberikan pekerjaan rumah yang memerlukan waktu sampai larut malam untuk menyelesaikannya. Sistem pendidikan seperti ini membuat motivasi anak untuk belajar menjadi pudar sebelum dewasa. Apabila tidak ada semangat, kegairahan serta rasa cinta untuk belajar, maka harapan untuk membentuk menusia unggul yang cerdas akal budinya, kreatif serta mampu memberikan solusi bagi masalah kehidupan akan gagal pula. Dengan demikian, peningkatan kualitas pembelajaran di sekolah haruslah mampu mengembangkan bakat dan kemampuan siswa secara optimal. Sehingga siswa dapat mewujudkan potensi dirinya serta dapat terlibat aktif dalam proses pembelajaran di sekolah.

Dalam hal ini para praktisi pendidikan khususnya pemerintah telah berusaha menghidupkan kembali aktivitas pendidikan melalui cara-cara pendidikan yang betul-betul mencerdaskan dan dapat dinikmati oleh anak didik. Hal ini terbukti dengan dikeluarkannya kebijakan-kebijakan pendidikan nasional oleh DEPDIKNAS, sebagaimana telah dijelaskan dalam UU SISDIKNAS pasal 40 ayat 2 yang berbunyi, "pendidikan dan tenaga kependidikan berkewajiban untuk menciptakan suasana pendidikan yang bermakna, kreatif, dinamis dan dialogis."2 Dari pasal tersebut, mengandung arti bahwa para pendidik atau seorang guru tidak boleh mendominasi pengetahuan peserta didik. Peserta didik harus diberi kebebasan dalam menggali pengetahuan. ${ }^{3}$ Dan guru harus lebih kreatif dalam menciptakan belajar yang menyenangkan, ramah, efektif dan efisien bagi siswa.

Model pembelajaran yang berkembang saat ini banyak bentuknya, antara yang satu dengan yang lain mempunyai karakteristik yang berbeda-beda. Pada dasarnya model pembelajaran yang diterapkan di sekolah bertujuan untuk memotivasi belajar siswa sehingga tercipta proses belajar mengajar yang kondusif dan menyenangkan. Model pembelajaran merupakan pola pembelajaran uang didesain sedemikian rupa, diterapkan dan dievaluasi secara sistematis dalam rangka mencapai tujuan pembelajaran yang efektif. Model pembelajaran merupakan hal yang mutlak dilakukan dalam rangka peningkatan mutu pendidikan. Proses pendidikan bisa berjalan efektif, apabila model pembelajaran yang diterapkan di kelas mampu menumbuhkan gairah siswa untuk belajar. ${ }^{4}$

\footnotetext{
2 Undang-undang RI, SISDIKNAS (Surabaya: Media Centre, 2005), 29.

${ }^{3}$ Salah satu alternatif yang bisa dilakukan adalah menciptakan pembelajaran yang efektif dan efisien. Pembelajaran seperti ini diharapkan dapat mengurangi beban peserta didik dalam proses belajar. Kasus di sekolah-sekolah yang membuat anak kehilangan semangat belajar dan pada dasarnya tidak ada seorang anak pun yang dilahirkan menjadi anak pemalas atau pemarah, oleh karena itu perlu adanya suasana yang menyenangkan, membebaskan dan demokratis.

${ }^{4}$ Sulhan, Pembangunan Karakter, 49.
}

Jurnal Pendidikan Agama Islam (Journal of Islamic Education Studies)

Volume 5 Nomor 1 (2017)

ISSN(p) 2089-1946\& ISSN(e) 2527-4511

Hal. 96 - 115 
Di antara sekian model pembelajaran yang ada, di sini penulis mencoba meneliti tentang model pembelajaran ramah anak, yang menerapkan pembelajaran yang menyenangkan, membebaskan dan demokratis. Pembelajaran ramah anak adalah suatu strategi pembelajaran yang lebih memperhatikan pada proses belajar dan pengembangan potensi anak, dalam hal ini seorang guru menyadari akan potensi anak didik dan perlu dikembangkan. Potensi itu bisa berkembang jika diberikan kepercayaan. Secara alamiah seorang yang dipercaya akan berusaha menjaga kepercayaan tersebut dengan sungguh-sungguh.

Konsep pembelajaran ramah anak di sini adalah penanaman rasa cinta kepada anak didik berupa kelembutan, bukan kekerasan. Karena kekerasan bukan jalan yang terbaik untuk mendidik anak apapun alasannya. Dengan kekerasan yang diberikan oleh guru hanya akan menyebabkan rasa takut yang mendalam bagi anak. Belajar dengan rasa takut tidak akan memperoleh hasil yang maksimal.5 Dengan hukuman yang salah dan kekerasan juga akan menimbulkan perasaan tersiksa pada diri anak, dan sekolah pun terkesan menjadi lembaga yang menakutkan dan jauh dari nilai pengasuhan. Dengan demikian, seharusnya baik struktur maupun budaya sekolah sebagai aspek tak nampak (invisible) menunjukkan perannya sebagai peredam kekerasan agar kekerasan langsung (direct) terjadi baik oleh sesama siswa maupun pendidik di sekolah. ${ }^{6}$ Dengan demikian, lingkungan pendidikan yang ramah akan menunjukkan perannya dalam pembelajaran anak untuk meningkatkan kualitas dirinya.

Dalam model pembelajaran ramah anak akan terjadi proses belajar sedemikian rupa sehingga siswa merasakan senang mengikuti pelajaran, tidak ada rasa takut, cemas dan was-was, siswa menjadi lebih aktif dan kreatif serta tidak merasa rendah diri karena bersaing dengan teman siswa lain. Diterapkan pula metode pembelajaran yang variatif dan inovatif, misalnya belajar tidak harus di dalam kelas, sehingga menghasilkan proses belajar yang efektif.

Sekolah, sesuai asal katanya, "escole" yang berarti tempat bermain, semestinya menjadi tempat yang menyenangkan bagi siswa. Maka dari itu dengan pembelajaran ramah anak diharapkan sekolah mampu menjadi rumah kedua bagi siswa sehingga mereka bisa tumbuh dan berkembang dengan kasih sayang. Karena dalam pembelajaran ini terdapat ikatan yang kuat antara guru dan siswa dalam suasana yang menyenangkan dan tidak ada tekanan baik fisik maupun psikologi. Sebab adanya tekanan apapun bentuknya hanya akan mengerdilkan

\footnotetext{
${ }^{5}$ Sulhan, Pembangunan Karakter, 89.

6 Auliya Ridwan, "Sistem Prevensi School Violence di Madura Berbasis Galtung Conflict Triangle”, Islamica, Vol. 3, No. 2, (Maret, 2009).
} 
pikiran dan mental siswa, sedangkan kebebasan dan kasih sayang apapun wujudnya akan dapat mendorong terciptanya iklim pembelajaran yang kondusif.7

Sementara, esensi pendidikan Islam tidak hanya tertuju kepada pembentukan akal saja, melainkan tertuju kepada setiap bagian jiwa sehingga setiap bagian jiwa itu menjadi mampu melaksanakan tugas sebagaimana dikehendaki oleh Allah.8 Sedangkan tujuan khusus pendidikan Islam ialah tujuan pendidikan agama pada setiap tingkatan. Untuk tingkat sekolah dasar, pendidikan agama Islam diberikan bertujuan untuk antara lain: menanamkan rasa agama terhadap siswa, menanamkan perasaan cinta kepada Allah dan rasul-Nya, memperkenalkan ajaran Islam yang bersifat global, membiasakan anak-anak berakhlak mulia, dan melatih anak-anak untuk merealisasikan ibadah yang bersifat praktis, serta membiasakan tauladan yang baik. ${ }^{9}$

Pendidikan Agama Islam di Indonesia ditempatkan pada kedudukan yang tinggi dalam sistem pendidikan nasional dan menjadi bagian yang tidak terpisahkan dengan perkembangan bangsa Indonesia. Pendidikan agama Islam mendapat prioritas utama. ${ }^{10}$ Namun terdapat pertentangan dengan praktik pendidikan agama saat ini, karena pendidikan tidak mampu memberdayakan peserta didik dalam penguasaan pengetahuan teoritis, penghayatan dan aplikasi dalam kehidupan sehari-hari. Dan juga terletak pada sistem pendidikan di antaranya mengenai model pembelajaran yang diterapkan kurang efektif dan efisien. ${ }^{11}$

Yang harus dipikirkan saat ini adalah bagaimana caranya agar implementasi PAI itu dapat sejalan dengan tujuan pendidikan nasional. Maka dengan konsep pembelajaran ramah anak yang didesain dengan metode yang variatif dan proses pembelajaran yang partisipatif, diharapkan mampu menciptakan anak didik yang berakhlak mulai sesuai dengan tujuan pendidikan Islam.

\section{B. Membaca Ulang Pendidikan Agama Islam}

Pendidikan agama Islam adalah upaya sadar dan terencana dalam menyiapkan peserta didik untuk mengenal, memahami, menghayati, hingga mengimani ajaran agama Islam, dibarengi dengan tuntunan untuk menghormati

${ }^{7}$ Achmad Sapari, "Pendidikan dan Sisitivitas Guru Yang Kreatif", Didaktika, (Desember 2003).

8 M. Ali Hasan dan Mukti Ali, Kapita Selekta Pendidikan Islam (Jakarta: Pedoman Ilmu Jaya, 2003), 45.

${ }^{9}$ H. Zuhairini, dkk, Metodik Khusus Pedidikan Agama (IAIN Sunan Ampel Malang: Usaha Offset Printing, 1983), 47.

${ }^{10}$ Hanun Asrohah, "PAI dan KBK", Nizamia, VII, 2 (Desember 2004), 147.

${ }^{11}$ Asrohah, "PAI dan KBK", 148.

Jurnal Pendidikan Agama Islam (Journal of Islamic Education Studies)

Volume 5 Nomor 1 (2017)

ISSN(p) 2089-1946\& ISSN(e) 2527-4511

Hal. 98 - 115 
penganut agama lain dalam hubungannya dengan kerukunan antar umat beragama hingga terwujud kesatuan dan persatuan bangsa. ${ }^{12}$

Sementara, kurikulum pendidikan agama Islam untuk sekolah dan madrasah berfungsi sebagai berikut: Pertama, pengembangan, yaitu meningkatkan keimanan dan ketakwaan peserta didik kepada Allah SWT yang telah ditanamkan dalam lingkungan keluarga. Pada dasarnya dan pertama-tama kewajiban menanamkan keimanan dan ketakwaan dilakukan oleh setiap orang tua dalam keluarga. Sekolah berfungsi untuk menumbuhkembangkan lebih lanjut dalam diri anak melalui bimbingan, pengajaran dan pelatihan agar keimanan dan ketakwaan tersebut dapat berkembang secara optimal sesuai dengan tingkat perkembangannya.

Kedua, penanaman diri, sebagai pedoman hidup untuk mencari kebahagiaan hidup di dunia dan akhirat. Ketiga, penyesuaian mental, yaitu untuk menyesuaikan diri dengan lingkungannya baik lingkungan fisik maupun lingkungan sosial dan dapat mengubah lingkungannya sesuai dengan ajaran Islam. Penyesuaian mental, yaitu untuk menyesuaikan diri dengan lingkungannya baik lingkungan fisik maupun lingkungan sosial dan dapat mengubah lingkungannya sesuai dengan ajaran agama Islam. Keempat, perbaikan, yaitu untuk memperbaiki kesalahan-kesalahan, kekurangankekurangan dan kelemahan-kelemahan peserta didik dalam keyakinan, pemahaman dan pengalaman ajaran dalam kehidupan sehari-hari.

Kelima, pencegahan, yaitu untuk menangkal hal-hal negatif dari lingkungannya atau dari budaya lain yang dapat membahayakan dirinya dan menghambat perkembangannya menuju manusia Indonesia seutuhnya. Keenam, pengajaran, tentang ilmu pengetahuan keagamaan secara umum (alam nyata dan nir-nyata), sistem dan fungsional. Ketujuh, penyaluran, yaitu untuk menyalurkan anak-anak yang memiliki bakat khusus di bidang agama Islam agar bakat tersebut dapat berkembang secara optimal sehingga dapat dimanfaatkan untuk dirinya sendiri dan bagi orang lain.

Dalam adagium uṣuliyyah dinyatakan bahwa: "Al-Umür bi Maqashīdihä", bahwa setiap tindakan dan aktivitas harus berorientasi pada tujuan atau rencana yang telah ditetapkan. Adagium ini menunjukkan bahwa pendidikan seharusnya berorientasi pada tujuan yang ingin dicapai, bukan semata-mata berorientasi pada sederetan materi. Karena itulah, tujuan pendidikan Islam menjadi komponen pendidikan yang harus dirumuskan terlebih dahulu sebelum merumuskan komponen-komponen pendidikan yang lain. ${ }^{13}$

12 Lihat Abdul Majid dan Dian Andayani, Pendidikan Agama Islam Berbasis Kompetensi (Bandung: Remaja Rosdakarya, 2006), 130.

${ }^{13}$ Abdul Mujib dan Jusuf Mudzakkir, Ilmu Pendidikan Islam (Jakarta: Kencana, 2006), 71. 
Tujuan merupakan standar usaha yang dapat ditentukan, serta mengarahkan usaha yang akan dilalui dan merupakan titik pangkal untuk mencapai tujuan-tujuan lain. Di samping itu, tujuan dapat membatasi ruang gerak usaha, agar kegiatan dapat terfokus pada apa yang dicita-citakan, dan yang terpenting lagi adalah dapat memberi penilaian atau evaluasi pada usaha-usaha pendidikan. ${ }^{14}$

Perumusan tujuan pendidikan agama Islam harus berorientasi pada hakekat pendidikan yang meliputi beberapa aspeknya, misalnya tentang: Pertama, tujuan dan tugas hidup manusia. Manusia hidup bukan karena kebetulan dan sia-sia. Ia diciptakan dengan membawa tujuan dan tugas hidup tertentu (QS. Ali Imran: 191). Tujuan diciptakan manusia hanya untuk mengabdi kepada Allah SWT. Indikasi tugasnya berupa ibadah (sebagai 'abdallah) dan tugas sebagai wakil-Nya di muka bumi (khalifah Allah). Firman Allah SWT.

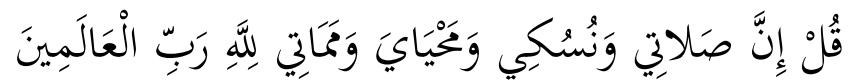

"Sesungguhnya salat, ibadah, hidup dan matiku hanyalah untuk Allah, Tuhan semesta alam" (Q.S. Al-An'am: 162). ${ }^{15}$

Kedua, memperhatikan sifat-sifat dasar (nature) manusia, yaitu konsep tentang manusia sebagai makhluk unik yang mempunyai beberapa potensi bawaan, seperti fitrah, bakat, minat, sifat, dan karakter, yang berkecenderungan pada al-Hanief (rindu akan kebenaran dari Tuhan) berupa agama Islam (Q.S. AlKahfi: 29) sebatas kemampuan, kapasitas, dan ukuran yang ada.16 Ketiga, tuntutan masyarakat. Tuntutan ini baik berupa pelestarian nilai-nilai budaya yang telah melembaga dalam kehidupan suatu masyarakat, maupun pemenuhan terhadap tuntutan kebutuhan hidupnya dalam mengantisipasi perkembangan dunia modern.

Keempat, dimensi-dimensi kehidupan ideal Islam. Dimensi kehidupan dunia ideal Islam mengandung nilai yang dapat meningkatkan kesejahteraan hidup manusia di dunia untuk mengelola dan memanfaatkan dunia sebagai bekal kehidupan di akhirat, serta mengandung nilai-nilai yang mendorong manusia berusaha keras untuk meraih kehidupan di akhirat yang lebih membahagiakan, sehingga manusia dituntut agar tidak terbelenggu oleh rantai kekayaan duniawi atau materi yang dimiliki.

\footnotetext{
${ }^{14}$ Ahmad D. Marimba, Pengantar Filsafat Pendidikan (Bandung: Al-Ma'arif, 1989), 45-46.

15 Departemen Agama RI, Al-Qur'an dan Terjemahnya (Bandung: Jumanatul Ali-ART, 2007), 107.

16 Hasan Langgulung, Manusia dan Pendidikan; Suatu Analisis Psikologis dan Pendidikan (Jakarta: Pustaka al-Husna, 1989), 34.
} 
Maka, esensi pendidikan agama Islam di sekolah/madrasah bertujuan untuk menimbulkan dan meningkatkan keimanan melalui pemberian dan pemupukan pengetahuan, penghayatan, serta pengalaman peserta didik tentang agama Islam sehingga menjadi manusia muslim yang terus berkembang dalam hal keimanan, amal shaleh, ${ }^{17}$ berbangsa dan bernegara, serta untuk melanjutkan pada jenjang pendidikan yang lebih tinggi.

Dalam hal pendidikan Islam secara praksis, al-Qur'an mendeskripsikannya dalam surat Ali Imran: 159, yang berbunyi: ${ }^{18}$

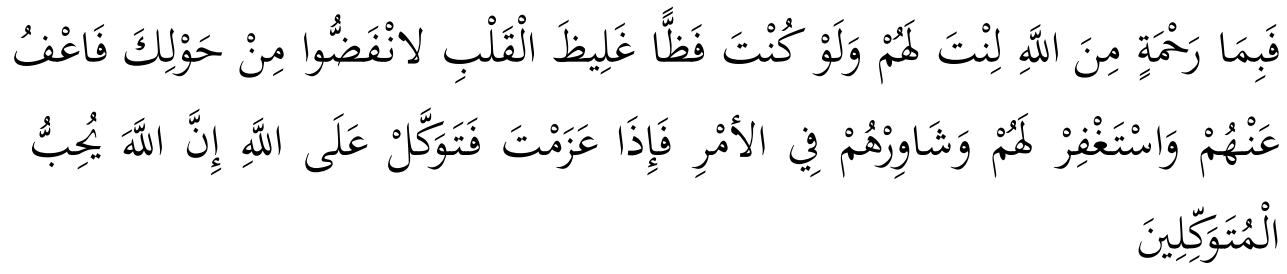

"Maka disebabkan rahmat dari Allah-lah kamu berlaku lemah-lembut terhadap mereka. Sekiranya kamu bersikap keras lagi berhati kasar, tentulah mereka menjauhkan diri dari sekelilingmu. Karena itu maafkanlah mereka, mohonkanlah ampun bagi mereka, dan bermusyawarahlah dengan mereka dalam urusan itu. Kemudian apabila kamu telah membulatkan tekad, maka bertawakallah kepada Allah. Sesungguhnya Allah menyukai orang-orang yang bertawakal kepada-Nya". (Q.S. Ali Imran: 159).

Perlu digarisbawahi dan dipahami oleh para guru dan orang tua dalam mendidik anak. Memang hukuman boleh diberikan kepada anak didik namun ada batasan dan tata caranya. Kita membutuhkan metode yang beragam untuk meluruskan kesalahan anak, karena tingkatan kesalahan tidak sama, dan untuk membenahi kesalahan-kesalahan tersebut membutuhkan cara-cara tertentu. Kadang-kadang kesalahan itu bersifat ringan seperti tidak memperhatikan kebersihan pakaian. Sementara ada juga kesalahan yang berat, seperti berkata bohong atau mencuri. Maka tidak disangsikan lagi, bahwa cara membenahi kesalahan ini berbeda dengan kesalahan yang pertama.

Di antara dua cara itu adalah dengan memukul yang tidak menyakitkan. ${ }^{19}$ Namun sayang sekali banyak orang yang menentang cara ini, karena dianggap sebagai cara yang tidak beradab. Berbicara tentang memukul dalam artian mendidik maka memukul yang dimaksud tentu saja yang tidak dilakukan terus menerus dan semata-mata untuk melampiaskan kemarahan. Cara guru menghukum siswa yang tidak sesuai dengan harapan bisa jadi berdampak besar

17 Lihat Sutikno, "Manusia dalam Konteks Pedagogis" Jurnal Pendidikan Agama Islam (Journal of Islamic Education Studies) Vol. 2 No. 1 (2014).

18 Departemen Agama RI, Al-Qur'an dan Terjemahnya, 71.

${ }^{19}$ Najib Khalid, Mendidik Cara Nabi SAW (Bandung: Pustaka Hidayah, 2002), 27-29. 
pada prestasi dan masa depan siswa. Hukuman siswa dimaksimalkan dengan mengkomunikasikan dengan nada tenang dan penuh kasih sayang. Dan dengan terfokus pada cara anak bisa berbuat lebih baik pada masa yang akan datang dan bukan pada kesalahan yang telah dilakukan. Dengan nuansa yang mendukung ini, siswa akan dengan jelas mendengar pesan guru, dan merasakan perhatian dibalik pesan itu serta menyadari bahwa hukuman yang diberikan untuk kebaikan dirinya walaupun terkadang siswa tidak menyukainya.

\section{Pendidikan Ramah Anak dalam Bingkai Pendidikan Islam}

Abraham Maslow, mengemukakan kebutuhan manusia secara hirarkis yaitu: ${ }^{20}$ kebutuhan biologi, kebutuhan rasa aman, kebutuhan rasa kasih sayang, kebutuhan rasa harga diri dan kebutuhan self realisasi. Dalam model pembelajaran ramah anak, kebutuhan rasa aman ditunjukkan dengan larangan penggunaan kekerasan, karena model pembelajaran ini menekankan pada perhatian dan perlindungan anak, misalnya: menjaga dan memberi rasa aman bagi anak, membantu mempertahankan dan melindungi anak dari bahaya dan pelecehan, mendorong anak untuk saling menjaga, tidak membolehkan pemberian hukuman fisik pada anak, memiliki petunjuk jelas tentang panduan antara siswa dan tidak membolehkan mempermainkan, mengolok-olok antar anak. Dalam Deklarasi Universal Hak Asasi Manusia (Universal Declaration of Human Rights) Pasal 3 dan Pasal 5 bahwa: "Setiap orang berhak untuk hidup bebas dan aman dari ancaman orang lain" (Pasal 3), "Tidak seorangpun boleh disiksa atau diperlakukan secara kejam, tidak manusiawi atau perlakuan penghinaan maupun hukuman" (Pasal 5). ${ }^{21}$

Kebutuhan rasa kasih sayang dan kebutuhan rasa harga diri, menghargai dan menyayangi adalah dua ekspresi emosi yang selalu patut ditunjukkan oleh orang tua kepada anaknya dan oleh guru kepada siswanya. Dua ekspresi emosi ini amat tulus diberikan oleh orang tua kepada buah hatinya, perasaan sayang dan dihargai yang diterima oleh anak membuat mereka selalu bersemangat untuk melaksanakan aktivitas yang tiada henti- henti-hentinya dalam menjalani proses pertumbuhan mereka. Perlu diketahui bahwa semua anak mempunyai harga diri sebagaimana orang dewasa. Mereka tidak ingin harga dirinya diinjakinjak walaupun oleh orang tuanya sendiri atau oleh gurunya. Mereka tetap ingin menjaga harga dirinya walaupun harus dengan cara melawan. Inilah hakekat manusia, yang tidak hanya berlaku pada orang dewasa saja, tetapi juga buat anak-anak. Sidney D. Craig mengatakan "sifat dasar manusia akan mengalami

${ }^{20}$ Khoiron Rosyadi, Pendidikan Profetik (Yogyakarta: Pustaka Pelajar Offset, 2004), 196.

21 Abdurrahman Asegaf, Pendidikan Tanpa Kekerasan (Jogjakarta: Tiara Wacana, 2004) 124125. 
gejolak perasaan menghargai yang amat dalam terhadap orang lain yang menawarkan kebaikan hati kepadanya".22 Dapat disimpulkan bahwasannya mengajar anak atau siswa dengan cara menumbuhkan budaya menghargai, memahami pertumbuhan diri anak dan mendidik mereka dengan cara memberikan pelayanan prima: senyum, ramah tamah dan penuh keakraban, akan memberikan dampak positif dalam pendidikan.

Kebutuhan self realisasi, masa balita adalah merupakan masa emas seorang anak, karena pada saat ini syaraf-syaraf berkembang pesat, dan pada saat yang sama orang tua memberikan pelayanan unggul dalam mendidik mereka, yaitu mendidik dan membesarkan yang penuh dengan senyum, kehangatan, sentuhan dan kata-kata positif. Mendidik dengan pelayanan prima masih diterima oleh anak, ketika mereka berada di bangku Taman Kanak-kanak dan berlanjut sampai kelas satu atau kelas dua SD. Pada saat ini orang tua di rumah masih memperlihatkan pribadi yang hangat pada anak di rumah. Di sekolah, di TK dan di SD, guru pun masih mendidik anak dengan penuh senyum, penuh sabar dan ramah tamah.

Mendidik dengan pelayanan ramah tamah, menghargai dan menyayangi dari guru kepada siswa, akan memberikan hasil yang menakjubkan. Inilah alasannya kalau dalam usia ini anak mampu merekam pembelajaran dengan hasil yang bagus. Namun, apabila ada yang beralasan bahwa dalam usia ini, daya tangkap anak ibarat menulis di atas batu, tetapi dididik oleh orang tua dan guru dengan penuh dengan suasana menekan, mengancam dan mengintimidasi maka pasti akan membuat anak menjadi manusia yang sedang membisu, tidak berkembang, tidak mampu merealisasikan bakat yang ia miliki.

Dalam proses biologi yang alami bila anak terus mengalami pertumbuhan, sampai akhirnya mereka memasuki usia pasca masa balita dan terus sampai pada masa pra remaja. Seiring dengan perubahan tubuh atau perubahan biologis mereka, maka karakter mereka juga ikut berubah. Bila pada masa bayi dan balita, mereka masih memperlihatkan sikap lucu dan manis. Namun dalam masa setelah itu mereka tumbuh menjadi manusia yang lebih agresif, implusif - kurang bisa menguasai diri, senang berteriak dan bergerak agresif dalam rangka merespon pertumbuhan jantung, paru-paru, otot dan organ yang lain seiring membuat mereka menjadi kontra dengan standar kebijakan guru dan orang tua.

Untuk mencegah gerak mereka yang agresif dan suara mereka yang keras, maka orang tua dan guru melakukan respon yang berbeda-beda. Sebagian orang tua dan guru berusaha untuk memahami pertumbuhan dan perkembangan

22 Sulhan, Pembangunan Karakter, 89. 
anak dan sebagian yang lain malah bersikap sangat otoriter, menghardik, mencela dan memberikan hukuman, dimana pada akhirnya akan melahirkan generasi muda yang senang membisu, pasif dan pemalu. Di saat anak mengalami pertumbuhan dan perkembangan yang pesat ini, walau mereka sendiri mengalami perubahan pola perilaku yang aneh-aneh di mata guru dan orang tua yang belum memahami bagaimana pertumbuhan dan perkembangan anak, sehingga mereka merespon dengan pola kekerasan atau budaya otoriter maka pastilah akan melahirkan anak-anak dengan perasaan tertindas.

Selama ini memang cukup bervariasi pola mengajar guru dan juga orang tua terhadap anak didik sejak masa anak-anak di SD sampai kepada masa remaja di tingkat SMP dan SLTA. Ada guru yang mengajar dengan cara memaksa, serba melarang, serba membantu, mendikte dan tentu ada juga guru dan orang tua yang mendidik anak dengan penuh menghargai, penuh kasih sayang, memberikan simpati dan rasa empati mereka. Tentu saja banyak orang tua dengan guru akan berkata bahwa berteori tentu lebih mudah dari pada mempraktekkannya. To say is easy but to do is difficult, namun pernyataan ini sedikit bisa disangkal.

Andai kata orang tua dan guru mau selalu belajar dan bisa memahami karakteristik anak sesuai dengan tingkat atau masa pertumbuhannya, maka mereka (kita) tentu akan mengerti mengapa anak pada usia 6 sampai 10 tahun, sebagai contoh, senang berbicara dan berkata dengan gaya menghardik-hardik. Mengapa dalam usia ini mereka bersikap sangat kinestetik, banyak bergerak dan bersikap tidak tenang. Dengan memahami karakter pertumbuhan anak didik akan bisa meredam gejolak emosi guru dan orang tua dalam mendidik.

Mengajar dengan gaya otoriter (menggunakan kekuasaan), atau gaya pseudo demokrasi bagi guru: marah-marah, mencela, mencerca, mengkritik, akan membuat siswa menutup pintu hati dan fikiran mereka. Anak didik akan kehilangan motivasi, minat dan gairah untuk berinteraksi dengan guru dan orang tua mereka. Mereka berharap agar pembelajaran dan saat-saat yang membosankan akan segera berakhir.

Guru-guru tertentu bisa jadi memiliki cara yang jitu untuk meredam keagresifan sikap mobile atau sikap anak didik. Cara yang mereka terapkan bukan lewat pemaksaan, menekan, atau marah-marah, namun dengan cara memberikan perlakuan khusus berupa keakraban, guru mengerti bahwa anakanak menjadi nakal karena mereka menderita skin hunger atau kulit yang lapar terhadap sentuhan. ${ }^{23}$ Maka sentuhan tangan guru pada pundak anak yang diikuti dengan senyum dan kata-kata simpati memiliki kekuatan yang besar untuk mengatasi prilaku nakal mereka. Sebagaimana yang ditulis oleh Bursteln dalam

${ }^{23}$ Sulhan, Pembangunan Karakter, 90.

Jurnal Pendidikan Agama Islam (Journal of Islamic Education Studies)

Volume 5 Nomor 1 (2017)

ISSN(p) 2089-1946\& ISSN(e) 2527-4511

Hal. 104 - 115 
buku Book on Children, bahwasanya "anak biasanya memberikan tanggapan (reaksi) yang lebih baik jika diberi senyum dan diajak bicara dengan sikap hangat dan penuh kasih sayang". ${ }^{24}$

Model pembelajaran ramah anak lebih banyak memberikan prasangka baik kepada anak (khusnudhan), artinya segala tingkah laku anak dianggap mempunyai tujuan baik, hanya saja terkadang langkahnya yang salah. Sehingga pendekatan yang dilakukan guru dengan pendekatan yang harus berupa motivasi bukan pemaksaan kehendak guru. Jadi pendekatan guru harus mampu mengubah sikap dengan penuh makna. Di sini guru menyadari akan potensi anak yang baik dan perlu dikembangkan. Potensi itu bisa berkembang jika diberikan kepercayaan. Perlu diketahui bahwa kepercayaan merupakan salah satu bentuk pengakuan diri dari satu pihak ke pihak lain. Secara alamiah seseorang yang dipercaya akan berusaha menjaga kepercayaan tersebut dengan sungguhsungguh.

Sementara itu, hal-hal yang harus diperhatikan dalam melaksanakan pembelajaran ramah anak adalah sebagai berikut: Pertama, mengerti tujuan dan fungsi belajar. Setiap guru harus mampu memahami konsep-konsep dasar dan cara belajar yang sesuai dengan tingkat perkembangan siswa. Siswa pada usia 612 tahun berbeda dengan manusia dewasa baik secara fisik maupun mentalnya. Walaupun sudah tersedia kurikulum dalam buku teks, pembelajaran yang hanya bersumber pada kurikulum dalam buku teks belum memadai. Untuk itu perlu memperdalam dari berbagai sumber termasuk pengalaman dalam berinteraksi dengan siswa.

Kedua, Segala kegiatan berpusat pada siswa. Artinya segala kegiatan pembelajaran bergerak dari ketertarikan siswa, memiliki kurikulum yang menunjukkan pada kebutuhan belajar siswa, lingkungan dan masyarakat, menerapkan metode yang sesuai dengan usia, kemampuan dan cara belajar siswa, mendorong siswa berpikir dan memutuskan sendiri, bertanya dan mengekspresikan pendapatnya. Pada dasarnya siswa dipandang sebagai makhluk Tuhan yang fitrah yang dimiliki, sebagai makhluk individu dan makhluk sosial. Setiap siswa memiliki perbedaan minat (interest), kemampuan (ability), kesenangan (preference), pengalaman (experience), dan cara belajar (learning style). ${ }^{25}$ Siswa tertentu mungkin lebih mudah belajar dengan cara mendengar dan membaca, siswa lain dengan cara melihat, dan siswa yang lain lagi dengan cara melakukan langsung (learning by doing). Oleh karena itu, kegiatan pembelajaran, organisasi kelas, materi pembelajaran, waktu belajar, alat belajar, dan cara penilaian perlu disesuaikan dengan karakteristik siswa. Kegiatan

24 Sulhan, Pembangunan Karakter, 90-91.

25 Sutrisno, Revolusi Pendidikan di Indonesia (Yogyakarta: Arruzz Media, 2005), 63. 
pembelajaran perlu menempatkan siswa untuk mengembangkan segenap bakat dan potensinya secara optimal.

Secara umum, cara belajar siswa dapat dikategorikan ke dalam empat hal, yakni cara belajar somatic, auditif, visual, dan intelektual. Cara belajar somatic adalah pola pembelajaran yang lebih menekankan pada aspek gerak tubuh atau belajar dengan melakukan. Cara belajar auditif adalah cara belajar yang lebih menekankan pada aspek pendengaran. Siswa akan cepat belajar jika materi disampaikan dengan ceramah atau alat yang dapat didengar. Cara belajar visual adalah cara belajar yang lebih menekankan pada aspek penglihatan. Siswa akan cepat menangkap materi pelajaran jika disampaikan dengan tulisan atau melalui gambar. Yang terakhir, cara belajar intelektual yang merupakan cara belajar yang lebih menekankan pada aspek penalaran atau logika. Siswa akan cepat menangkap materi jika pembelajaran dirancang dengan menekankan pada aspek mencari solusi pemecahan.

Di sisi lain setiap siswa juga mempunyai kecerdasan yang dapat dioptimalkan melalui kegiatan pembelajaran. Kecerdasan yang dimaksud adalah kecerdasan linguistic, logis matematis, spasial, musical, kinestetis jasmani, interpersonal, intrapersonal, dan naturalis. ${ }^{26}$ Sebagaimana diuraikan sebelumnya bahwa setiap siswa lahir dalam keadaan berbeda (individual difference) dan masing-masing mempunyai potensi yang dapat dikembangkan. Karena itu kegiatan pembelajaran diciptakan sedemikian rupa sehingga membuat siswa mengoptimalkan potensinya. Karena itu dalam kegiatan pembelajaran harus dikondisikan agar siswa mempunyai kesempatan dan kebebasan dalam mengembangkan diri sesuai dengan kecenderungan masing-masing. Guru hendaknya berupaya memberikan kesempatan kepada siswa untuk mengungkapkan pendapatnya sebanyak mungkin.

Ketiga, Meningkatkan kualitas pembelajaran. Artinya pola pendidikan selalu memastikan akan menguasai kemampuan dasar menulis, membaca, berbicara, mendengar dan ketrampilan yang diperlukan sepanjang hidupnya. Mendorong anak untuk belajar sambil bekerja dan bekerja dengan orang lain. Juga memastikan gurunya berkualitas dan secara terus menerus menjadikan gurunya lebih baik, memastikan gurunya dan stafnya selalu dalam kondisi prima dan digaji cukup serta memiliki motivasi tinggi.

Keempat, Mendorong anak berpartipasi dalam kegiatan sekolah dan masyarakat. Artinya bahwa kegiatan pembelajaran tidak hanya mengoptimalkan kemampuan individual siswa secara internal, melainkan juga mengasah kemampuan siswa untuk membangun hubungan dengan pihak lain. Karena itu, kegiatan pembelajaran harus dikondisikan yang memungkinkan siswa

${ }^{26}$ Sutrisno, Revolusi Pendidikan di Indonesia, 64.

Jurnal Pendidikan Agama Islam (Journal of Islamic Education Studies)

Volume 5 Nomor 1 (2017)

ISSN(p) 2089-1946\& ISSN(e) 2527-4511

Hal. 106 - 115 
melakukan interaksi dengan siswa lain, interaksi siswa dengan guru, dan siswa dengan masyarakat. Dengan pemahaman ini, guru dapat menerapkan berbagai metode pembelajaran yang memungkinkan siswa terlibat dengan pihak lain, misalnya diskusi, pro-kontra, sosiodrama, pariwisata, dan lain-lain.

\section{Corak Pendidikan Ramah Anak; Pendekatan Instruksional}

Konsep pembelajaran ramah anak itu berusaha mengikutsertakan partisipasi anak dalam perencanaan proses belajar mengajar, anak didik diajak berdiskusi tentang sekolah impian mereka (dream school). Sekolah, sesuai asal katanya "escole" yang berarti tempat bermain, semestinya mampu menjadi tempat yang menyenangkan bagi siswa. Didiklah anak dengan cinta, itulah kata yang tepat untuk mendidik anak saat ini. Karena kekerasan bukanlah jalan yang terbaik untuk mendidik anak apapun alasannya. Kekerasan yang ditampilkan oleh guru hanya akan menyebabkan rasa takut yang mendalam bagi anak. Belajar dengan rasa takut tidak akan memperoleh hasil yang maksimal. ${ }^{27}$

Perkataan kasar dan pemberian hukuman yang salah adalah hal yang tidak diingini oleh semua anak walaupun menurut orang tua dan guru demi kebaikan anak. Namun dengan hal itu anak merasakan bahwa kemarahan yang ditampilkan tersebut adalah sebagai bentuk ketidaksenangan terhadap dirinya. Oleh karena itu, satu kunci paling ampuh dalam mendidik anak adalah dengan berlaku lemah lembut dengan penuh cinta kasih walau dalam keadaan marah sekalipun.

Dalam model pembelajaran ramah anak, guru lebih bersikap demokratis. Guru banyak mengenal karakter anak, guru sadar akan karakter anak yang berbeda-beda dan guru paham benar dengan kebutuhan sesuai dengan usia anak. Sehingga dengan itu guru tidak akan memaksakan kehendak kepada siswa agar selalu mengikutinya, bukan berarti anak dibiarkan liar, akan tetapi pendekatan guru lebih menata perasaan yang masih labil.

Secara garis besar, pembelajaran ramah anak adalah sebagai berikut, serta dibedakan menjadi beberapa hal:

1. Sikap guru yang efektif

Sebagai teladan, guru harus memiliki kepribadian yang dapat dijadikan profil dan idola, seluruh kehidupannya adalah figur yang paripurna. Itulah kesan terhadap guru sebagai sosok yang ideal. Guru adalah mitra anak didik dalam kebaikan, guru yang baik, anak didikpun menjadi baik. Sebagai seorang guru harus mampu menjadi teladan bagi siswanya dengan menunjukkan kepribadian yang sempurna. Seorang guru yang efektif adalah

27 Sulhan, Pembangunan Karakter Pada Anak, 89. 
guru yang bersifat demokratis. Dalam pembelajaran ramah anak, seorang guru lebih banyak mengenal karakter anak didik dan paham kebutuhan anak didik sesuai dengan usianya. Guru tidak boleh memaksakan kehendaknya kepada siswa agar selalu mengikutinya, bukan berarti anak dibiarkan liar. Di sini pendekatan guru lebih banyak menata perasaan yang masih labil.

Dengan model pembelajaran ramah anak, ada kondisi yang sehat, yang terjalin antara guru dan siswa. Segala persoalan yang mengangkut siswa, diselesaikan dengan kepala dingin, tidak harus dengan tindakan dan suara yang keras. Perlu diketahui bahwa semua anak mempunyai harga diri sebagaimana orang dewasa. Mereka tidak ingin harga dirinya diinjak-injak walaupun oleh orang tuanya sendiri atau oleh gurunya.

Guru adalah tokoh yang paling utama dalam membimbing anak di sekolah dan mengembangkan anak agar mencapai kedewasaan. Oleh karena itu, hal yang pertama-tama harus diperhatikan guru untuk dapat menarik minat siswa ialah penampilan dan sikapnya. Usahakan jangan terlalu formal dan penuh disiplin, agar anak tidak takut dan enggan di sekolah. Guru harus mampu menjadi tokoh yang berkesan dan berwibawa. ${ }^{28}$

Secara garis besar karakteristik sikap guru terhadap siswa, dalam pembelajaran ramah anak adalah perlakuan adil bagi murid laki-laki perempuan, cerdas - lemah, kaya - miskin, normal - cacat, anak pejabat anak buruh, penerapan norma agama, sosial dan budaya setempat, kasih sayang kepada siswa, memberikan perhatian bagi mereka yang lemah dalam proses belajar. Memberikan hukuman fisik akan membuat anak trauma dan saling menghormati hak-hak anak baik antara siswa, antara tenaga kependidikan serta antara tenaga kependidikan dan siswa. Contoh: guru dan /atau kepada sekolah menunggu kedatangan siswa di depan sekolah pada pagi hari dengan raut muka ceria dan berjabat tangan serta memberikan ucapan "salam", "selamat pagi" kepada siswa.

2. Proses pembelajaran yang efektif

Dalam proses belajar mengajar, guru harus memberikan peluang besar dalam mencapai tujuan pendidikan, menurut anak didik melakukan kegiatan belajar secara optimal, merumuskan bahan pelajaran harus diatur agar memotivasi anak didik untuk mempelajarinya. Semua kegiatan pada proses pembelajaran harus dipusatkan pada siswa, dengan dibantu penerapan metode yang bervariatif, alat, dan sumber belajar harus benarbenar dipilih oleh guru agar menumbuhkan belajar aktif anak didik, bukan mengajar aktif guru.

28 Yulia Singgih D. Gunarsa, Psikologi Perkembangan Anak dan Remaja (Jakarta: BPK Gunung Media, 2003), 111.

Jurnal Pendidikan Agama Islam (Journal of Islamic Education Studies)

Volume 5 Nomor 1 (2017)

ISSN(p) 2089-1946\& ISSN(e) 2527-4511

Hal. 108 - 115 
Dalam proses pembelajaran ramah anak, secara garis besar ditandai sebagai berikut: Pertama, dalam proses belajar mengajar dengan menerapkan model pembelajaran ramah anak, terjadi proses belajar sedemikian rupa sehingga siswa merasa senang mengikuti pelajaran, tidak ada rasa takut, cemas, dan was-was, siswa menjadi lebih aktif dan kreatif serta tidak merasa rendah diri karena bersaing dengan teman siswa lain. Kedua, erjadi proses belajar yang efektif dihasilkan oleh penerapan metode pembelajaran yang variatif dan inovatif. Misalnya belajar tidak harus dalam kelas, guru sebagai fasilitator proses belajar menggunakan alat bantu untuk meningkatkan ketertarikan dan kesenangan dalam pengembangan kompetensi, termasuk lingkungan sekitar sekolah sebagai sumber belajar seperti pasar, kebun, sawah, sungai, laut dan lain-lain.

Ketiga, proses belajar mengajar didukung oleh media ajar seperti buku pelajaran dan alat bantu ajar, sehingga membantu daya serap siswa. Guru sebagai fasilitator menerapkan proses belajar mengajar yang kooperatif, interaktif baik belajar secara individu maupun kelompok. Keempat, terjadi proses belajar yang partisipatif, murid lebih aktif dalam proses belajar. Guru sebagai fasilitator proses belajar mendorong dan memfasilitasi siswa dalam menemukan cara atau jawaban sendiri dalam suatu persoalan. Kelima, siswa dilibatkan dalam berbagai aktifitas yang mengembangkan kompetensi dengan menekankan proses belajar melalui berbuat sesuatu (learning by doing, demo, praktek, dan lain-lain).

3. Pengelolaan kelas yang efektif

Masalah pokok yang dihadapi guru, baik pemula maupun yang sudah berpengalaman adalah pengelolaan kelas. Pengelolaan kelas ${ }^{29}$ merupakan masalah yang kompleks. Guru menggunakannya untuk menciptakan dan mempertahankan kondisi kelas untuk mencapai tujuan pengajaran secara efisien dan memungkinkan anak didik dapat belajar. Dengan demikian, pengelolaan kelas yang efektif adalah syarat bagi proses pembelajaran yang efektif. ${ }^{30}$

Dalam pengelolaan kelas diupayakan anak didik bisa termotivasi dalam belajar dengan melibatkan mereka di dalamnya, misalnya: pertama, siswa dilibatkan dalam penataan bangku, dekorasi dan ilustrasi yang

${ }^{29}$ Pengelolaan kelas adalah proses seleksi dan penggunaan alat yang tepat terhadap problem dan situasi kelas. Ini berarti guru bertugas menciptakan, memperbaiki, dan memelihara sistem atau organisasi kelas. Sehingga anak didik dapat memanfaatkan kemampuannya, bakatnya dan potensinya.

30 Untuk menciptakan proses pembelajaran yang efektif, perlu memperhatikan pengaturan atau penataan ruang kelas, penyusunan dan pengaturan ruang kelas hendaknya memungkinkan anak didik berkelompok dan memudahkan guru bergerak secara leluasa. 
menggambarkan ilmu pengetahuan. Penataan bangku secara klasikal (berbaris ke belakang) mungkin akan membatasi kreatifitas siswa dalam interaksi sosial dan kerja diskusi kelompok. Oleh sebab itu dalam penataan bangku dapat diatur seefektif mungkin untuk kepentingan proses belajar.

Kedua, siswa dilibatkan dalam menentukan warna dinding atau dekorasi dinding kelas, sehingga siswa menjadi betah di dalam kelas. Ketiga, siswa dilibatkan dalam memajang hasil karyanya, hasil ulangan atau tes, bahan ajar dan buku sehingga artistik dan menarik serta menyediakan tempat khusus untuk baca. Keempat, bangku dan kursi sebaiknya ukurannya disesuaikan dengan ukuran postur anak Indonesia serta mudah untuk digeser guna menciptakan kelas yang dinamis.

4. Lingkungan belajar yang kondusif

Kondisi lingkungan di sekolah akan sangat berpengaruh terhadap proses belajar siswa. Sekolah yang fasilitasnya lengkap dengan sekolah yang kurang fasilitasnya, pengaruhnya sangatlah berbeda. Sekolah yang fasilitasnya lengkap akan sangat membantu guru dalam mengajar serta mampu menumbuhkan motivasi belajar siswa.

Dalam pembelajaran ramah anak, lingkungan belajar yang kondusif dapat dicirikan sebagai berikut: (1) Siswa dilibatkan dalam mengungkapkan gagasan dalam menciptakan lingkungan sekolah (penentuan warna dinding kelas, hiasan, kotak saran, majalah dinding, taman kebun sekolah, dan lainlain); (2) Tersedia fasilitas air bersih, hygiene san sanitasi kebersihan dan fasilitas kesehatan; (3) Fasilitas sanitasi seperti toilet, orinoir, tempat cuci, disesuaikan dengan postur dan usia anak. Misalnya: Bak mandi yang tidak terlalu tinggi sehingga bisa dijangkau oleh tangan anak; (4) Di sekolah diterapkan kebijakan atau peraturan yang mendukung kebersihan dan kesehatan. Kebijakan dan peraturan ini disepakati, dikontrol dan dilaksanakan oleh semua siswa.

\section{E. Humanisasi Sistem Pembelajaran}

Model pembelajaran ramah anak diterapkan karena masih adanya tindak kekerasan yang dilakukan oleh guru pada anak dalam pembelajaran di sekolah. Penyebab dari adanya kekerasan terhadap anak amat mudah terjadi, salah satu penyebabnya adalah karena banyak orang yang kurang mengenal dengan baik pengertian maupun batasan kekerasan terhadap anak. Bahkan kadang definisi kekerasan sering dipandang sebelah mata oleh sebagian orang. Definisi kekerasan sendiri adalah "semua bentuk perlakuan salah secara fisik atau emosional, penganiayaan seksual, penelantaran, eksploitasi secara komersial, dan lain-lain yang mengakibatkan gangguan nyata atau potensial terhadap 
perkembangan kesehatan, kelangsungan hidup anak dan terhadap martabatnya dalam konteks hubungan yang bertanggung jawab, kepercayaan atau kekuasaan" (UNICEF, 2002).

Adapun macam atau indikator dari kekerasan adalah: ${ }^{31}$ Pertama, kekerasan yang bersifat terbuka, yakni kekerasan yang dapat dilihat atau diamati secara langsung, seperti perkelahian, atau kekerasan yang berkaitan dengan fisik. Kedua, kekerasan yang bersifat tertutup, yakni kekerasan tersembunyi atau tidak dilakukan secara langsung, seperti mengancam, intimidasi, atau simbolsimbol lain yang menyebabkan pihak-pihak tertentu merasa takut dan tertekan. Ketiga, kekerasan yang bersifat agresif (offensive), yakni kekerasan yang dilakukan untuk mendapatkan sesuatu, seperti perampasan, pencurian, bahkan pembunuhan.

Dalam dunia pendidikan, bentuk kekerasan yang sering dilakukan oleh guru terhadap anak didik adalah kekerasan ringan dan bersifat tertutup, yang berupa penekanan psikis, seperti: kemarahan guru, hukuman yang pada akhirnya menyebabkan rasa takut yang mendalam pada anak didik. Sebagai contoh, seorang guru membentuk siswanya agar mau duduk manis dan mendengarkannya, hal seperti ini sering terjadi dimanapun dan hal itu dianggap sebagai suatu kewajaran, padahal seorang guru telah melakukan kekerasan emosional, yang akibatnya buruk pada kondisi psikis anak didik, masih banyak sekali kekerasan dalam pendidikan dan bahkan kekuasaan (dominasi) guru terhadap anak didik dapat dikategorikan sebagai kekerasan, karena guru dipandang sebagai sosok dictator yang membelenggu kreatifitas anak didik.

Dalam paradigma lama, proses pembelajaran di sekolah memang masih ada guru yang merasa berkuasa dan berusaha mendominasi siswa. Dari paradigma lama itu terjadilah fenomena D4 (datang, duduk, dengar, dan diam) sehingga siswa menjadi terpasung dengan iklim belajar yang tidak menyenangkan. ${ }^{32}$ Terasa sekolah bagaikan "penjara" yang telah membelenggu inspirasi dan kreatifitas siswa, bakatnya, serta potensi dasarnya sebagai manusia yang unik dan berbeda antara yang satu dengan yang lain. Proses pembelajaran sudah menjadi tidak menyenangkan lagi, dan peserta didik banyak yang kurang terlayani untuk mengembangkan bakat dan minat yang dimilikinya. ${ }^{33}$ Dalam hal ini siswa menjadi anak yang pasif, padahal siswa adalah komponen terpenting dalam pembelajaran, yang pada dasarnya "ia" adalah unsur penentu dalam proses belajar mengajar. ${ }^{34}$

\footnotetext{
${ }^{31}$ Abdurrahman Asegaf, Pendidikan Tanpa Kekerasan (Jogyakarta: Tiara Wacana, 2004), 37.

${ }^{32}$ Suparlan, Menjadi Guru Efektif (Yogyakarta: Hikayat, 2005), 43.

33 Suparlan, Menjadi Guru Efektif, 67.

34 Oemar Hamalik, Proses Belajar Mengajar (Jakarta: Bumi Aksara, 2004), 99.
} 
Paulo Freire, Ivan Illich, Arief Rahman, J. Drost, dan masih banyak tokoh pembaharu dalam bidang pendidikan telah menyampaikan kritiknya terhadap guru dan sekolah dewasa ini. Indra Jati Sidi, Direktur Jenderal Pendidikan Dasar dan Menengah, dalam banyak kesempatan berusaha untuk 'melepaskan bajunya' sebagai Direktur Jenderal, dan mengkritik dunia pendidikan yang terlalu akademis dan adanya proses pembelajaran yang tidak menyenangkan. Dari kritik inilah lahirlah konsep pembelajaran yang aktif dan menyenangkan bagi siswa.

Bahkan di tengah derasnya arus kekerasan yang selama ini kurang adanya kesadaran dari guru, praktisi-praktisi pendidikan merasa bahwa perlu diterapkannya pendekatan baru yaitu pentingnya menempuh pendekatan kelembutan terhadap anak, dan salah satunya tempat yang paling besar peluangnya untuk melakukan kelembutan terhadap anak adalah sekolah.

Dalam Negara Kesatuan Republik Indonesia (NKRI) - yang notabenenya mayoritas masyarakatnya memeluk agama Islam - seharusnya Pendidikan Agama Islam (PAI) mendasari pendidikan-pendidikan lain, serta menjadi primadona bagi masyarakat, orang tua, dan peserta didik. Pendidikan agama Islam juga seharusnya mendapat waktu yang proporsional, tidak saja di madrasah atau di sekolah-sekolah yang bernuansa Islam, tetapi juga di sekolahsekolah umum. Demikian halnya dalam upaya peningkatan mutu pendidikan, PAI harus dijadikan tolak ukur dalam membentuk watak dan pribadi peserta didik, serta membangun moral bangsa.

Secara jujur harus diakui bahwa PAI masih belum mendapat tempat dan waktu yang proporsional, terutama di sekolah umum. Lebih dari itu, karena tidak termasuk kelompok mata pelajaran yang di-UAN-kan. Keberadaannya seringkali kurang mendapat perhatian. Pendidikan agama Islam di sekolah atau madrasah, dalam pelaksanaannya masih menunjukkan berbagai permasalahan yang kurang menyenangkan. Hal tersebut seperti dikemukakan oleh Dirjen Kelembagaan Agama Islam Departemen Agama sebagai berikut: (1) Islam diajarkan lebih pada hafalan, padahal Islam penuh dengan nilai-nilai (values) yang harus dipraktekkan. (2) Pendidikan agama lebih ditekankan pada hubungan formalitas antara hamba dan Tuhannya. (3) Penalaran dan argumentasi berpikir untuk masalah-masalah keagamaan kurang mendapat penekanan. (4) Penghayatan nilai-nilai agama kurang mendapat penekanan. (5) Menatap lingkungan untuk kemudian memasukkan nilai Islam sangat kurang mendapat perhatian (orientasi pada kenyataan kehidupan sehari-hari kurang). (6) Metode pembelajaran agama, khususnya yang berkaitan dengan nilai-nilai Islam kurang mendapatkan penggarapan. (7) Ukuran keberhasilan pendidikan agama juga masih formalitas (termasuk verbalistis). (8) Pendidikan agama belum mampu menjadi landasan kemajuan dan kesuksesan untuk mata pelajaran lain. (9) Pendidikan agama 
belum dijadikan fondasi pendidikan karakter peserta didik dalam perilaku keseharian. ${ }^{35}$

Setelah ditelusuri pendidikan agama Islam di sekolah menghadapi beberapa kendala, antara lain waktu yang disediakan hanya 2 jam pelajaran dengan mantan materi yang begitu padat dan memang penting, yakni menuntut pemantapan pengetahuan hingga terbentuk watak dan kepribadian yang berbeda dengan tuntutan terhadap mata pelajaran lainnya. Kelemahan lain adalah materi pendidikan agama Islam, termasuk bahan ajar akhlak yang lebih terfokus pada pengayaan pengetahuan (kognitif) dan minim dalam pembentukan sikap (efektif) serta pembiasaan (psikomotorik). Selain itu, kurangnya keikutsertaan guru pendidikan agama Islam dalam memberikan motivasi kepada peserta didik untuk mempraktekkan nilai-nilai pendidikan agama dalam kehidupan sehari-hari. Lemahnya sumber daya guru dalam pengembangan pendekatan dan metode yang bervariatif, minimnya berbagai sarana pelatihan dan pengembangan, serta rendahnya peran serta orang tua siswa.

Dengan konsepsi pendidikan ramah anak, maka terdapat pengaruh yang besar pada pendidikan agama Islam. Mengingat tolak ukur keberhasilan PAI adalah aplikasi yang diwujudkan dalam prilaku sehari-hari. Dengan pendekatan yang ramah dan penuh dengan penanaman motivasi dari guru maka akan mampu mendorong semangat siswa, dan menumbuhkan tanggung jawab siswa, dan dengan metode yang bervariasi serta pengelolaan kelas yang efektif akan mampu menimbulkan suasana yang menyenangkan dalam pembelajaran sehingga tidak ada kondisi yang terkesan menekan siswa. Karena di dalam pendekatan ini menyakitkan peran siswa dalam pembelajaran.

\section{F. Kesimpulan}

Konsep ramah anak berupaya untuk menciptakan pembelajaran yang menyenangkan dan membuat siswa merasa betah dan nyaman di sekolah. Hal tersebut dapat dilihat dari sikap guru yang ramah terhadap siswa, proses pembelajaran yang efektif, pengelolaan kelas yang efektif dan lingkungan belajar yang kondusif, serta dapat menciptakan motivasi belajar siswa. Dalam hal internalisasi nilai-nilai keislaman, guru menanamkan sikap sabar dan mampu menjadi teladan bagi siswa, serta sebagai upaya pendukung dalam proses pembelajarannya menggunakan metode yang bervariatif, pengelolaan kelas yang menyenangkan, serta didukung lingkungan belajar yang kondusif. Semuanya itu dimaksudkan demi tercapainya tujuan pendidikan agama Islam secara maksimal. Guru adalah suri tauladan bagi anak didik, penampilan serta sikap guru selalu

35 Majid dan Andayani, Pendidikan Agama Islam Berbasis Kompetensi, iv. 
menjadi perhatian bagi anak didik. Oleh karena itu, dalam menciptakan interaksi positif, guru perlu bersikap lebih ramah terhadap anak didik di sekolah, sehingga anak didik merasa nyaman dalam proses belajar mengajar.

\section{G. Referensi}

Asegaf, Abdurrahman. Pendidikan Tanpa Kekerasan. Jogjakarta: Tiara Wacana, 2004.

Asrohah, Hanun. "PAI dan KBK”. Nizamia, VII, 2 (Desember 2004).

Departemen Agama RI. Al-Qur'an dan Terjemahnya. Bandung: Jumanatul Ali-ART, 2007.

Gunarsa, Yulia Singgih D. Psikologi Perkembangan Anak dan Remaja. Jakarta: BPK Gunung Media, 2003.

Hamalik, Oemar. Proses Belajar Mengajar. Jakarta: Bumi Aksara, 2004.

Hasan, M. Ali., dan Ali, Mukti. Kapita Selekta Pendidikan Islam. Jakarta: Pedoman Ilmu Jaya, 2003.

Khaid, Najib. Mendidik Cara Nabi SAW. Bandung: Pustaka Hidayah, 2002.

Langgulung, Hasan. Manusia dan Pendidikan; Suatu Analisis Psikologis dan Pendidikan. Jakarta: Pustaka al-Husna, 1989.

Majid, Abdul., dan Andayani, Dian. Pendidikan Agama Islam Berbasis Kompetensi. Bandung: Remaja Rosdakarya, 2006.

Marimba, Ahmad D. Pengantar Filsafat Pendidikan. Bandung: Al-Ma'arif, 1989.

Mujib, Abdul., dan Mudzakkir, Jusuf. Ilmu Pendidikan Islam. Jakarta: Kencana, 2006.

Ridwan, Auliya. "Sistem Prevensi School Violence di Madura Berbasis Galtung Conflict Triangle", Islamica, Vol. 3, No. 2, (Maret, 2009).

Rosyadi, Khoiron. Pendidikan Profetik. Yogyakarta: Pustaka Pelajar Offset, 2004.

Sapari, Achmad. "Pendidikan dan Sisitivitas Guru Yang Kreatif". Didaktika, 08 Desember 2003.

Sulhan, Najib. Pembangunan Karakter Pada Anak, Manajemen Pembelajaran Guru Menuju Sekolah Efektif. Surabaya: Intelaktual Club, 2006.

Suparlan. Menjadi Guru Efektif. Yogyakarta: Hikayat, 2005.

Sutikno. "Manusia dalam Konteks Pedagogis." Jurnal Pendidikan Agama Islam (Journal of Islamic Education Studies), Vol. 2 No. 1 (2014). 
Sutrisno. Revolusi Pendidikan di Indonesia. Yogyakarta: Arruzz Media, 2005.

Undang-undang RI. SISDIKNAS. Surabaya: Media Centre, 2005.

Zuhairini. Metodik Khusus Pedidikan Agama. IAIN Sunan Ampel Malang: Usaha Offset Printing, 1983. 